\title{
Defending Campus Culture Against the Threat of Perennial Online Instruction in a Post-COVID-19 World
}

\author{
Rhoda M. Scherman ${ }^{1 *}$ and Nancy E. Snow ${ }^{2}$ \\ ${ }^{1}$ Department of Psychology and Neuroscience, Auckland University of Technology, Auckland, New Zealand, ${ }^{2}$ Institute for the \\ Study of Human Flourishing and Philosophy, The University of Oklahoma, Norman, OK, United States
}

Keywords: emergency remote teaching, COVID-19, campus culture, student flourishing, online teaching and learning, in-person teaching and learning, global citizenship, intellectual virtues

Until recently, higher education was a mainly in-person institution. Students either commuted from their homes to nearby campuses, or they lived at school, in campus accommodations or in nearby private housing - all so they could more easily access and spend time on the college campus. This is because higher education settings are so much more than just "information delivery systems," they are, as Herman (2020) reports, “. . like small towns.” They are sites for the development of students as not just learners but also as people and citizens.

While many degree programs offer online courses and distance learning ${ }^{1}$, colleges and universities have traditionally been physical sites that consist of in-person classroom instruction and interaction. We argue that it is this physicality of colleges and universities that fosters social interactions, orchestrating the conditions for the creation of communities of learners, which further facilitates personal and intellectual growth. We see this as "campus culture" and argue that it is both the condition for, and the product of, student flourishing. We further argue that it is something essential to the higher education, and therefore, should be protected, at a time when so many would like to see higher education permanently move off campus and online (e.g., Dhawan, 2020; Frankfurt, 2020; Govindarajan and Srivastava, 2020; Lockee, 2021; Taparia, 2020, May 25).

We are, as Aristotle thought, social animals. By that argument, learning should be seen as a communal activity. Moreover, it is made possible by the development of certain kinds of virtues-what have been called "intellectual virtues," such as curiosity, love of learning, openmindedness, and intellectual humility. These are the virtues people need, in order to pursue truth and knowledge (Baehr, 2017). Learning as a communal activity is also made possible by "interpersonal virtues" of cooperation, mutual respect and good will toward others in the class, and by the creation of norms of trust that allow students to learn in a space in which they know their contributions will be valued. In an important sense, universities do not just teach subjects like philosophy, psychology or business; they teach people-who learn from each other as much as they do

This article was Educational Psychology, a section of the journal Frontiers in Education

Received: 17 September 2020 Accepted: 25 October 2021

Published: 23 November 2021

Citation:

Scherman RM and Snow NE (2021) Defending Campus Culture Against the Threat of Perennial Online Instruction in a Post-COVID-19 World. Front. Educ. 6:607655. doi: 10.3389/feduc.2021.607655 
from their professors. Together they develop intellectual virtues and virtues of social cooperation, which we believe can only be achieved when in the company of others.

By being in-person and together on campus, students are also better able to make new acquaintances and form friendships that go beyond the boundaries of the classroom (Eve et al, 2014). Importantly, students also develop a sense of identity and belonging. The social opportunities and interpersonal interactions made possible by in-person and on-campus attendance help students to see themselves as parts of a greater whole; connecting their personal good with that of the school, thereby contributing to its good, and enhancing the lives of fellow students-which in turn enhances their own lives.

Consider the kinds of social interactions that occur on campus, through students' engagement in groups and organizations such as (e.g.,) a campus Gay Straight Alliance; or in the context of a multicultural student center. Students engage with other students who might feel disenfranchised or who lack a sense of true belonging (Lefever, 2012). Such campus groups and settings can help students to overcome feelings of loneliness, depression, or alienation. It is also in these settings that students often form lasting friendships (Alemán, 2010; Gareis et al, 2019). Lending support to our claims, Gable (2016) compared the experiences of first-generation and continuinggeneration students. She reported that for both groups, a student's path to "thriving" included "making friends from a variety of backgrounds... (and) ... committing (to) an extra-curricular organization preferably early in college." (Gable, 2016, p. 221).

In short, colleges and universities, with the help of the student organizations within-and the campus culture that is created-are microcosms that quite literally (if not physically), surround, support and aid students in myriad ways. This includes helping students form meaningful friendships and develop social networks; and helping with learning - not just the attainment of knowledge in pursuit of a degree, but learning about oneself-as an individual and as part of something bigger. These are some of the interpersonal and associative skills that underpin the intellectual and interpersonal virtues, which in turn, translate to becoming good citizens (Peterson, 2017). Interestingly, universities are increasingly being looked to as places that produce global citizens (Braskamp, 2008; Grimwood, 2018).

In 2020, the COVID-19 pandemic forced educators to revisit the pros and cons of online teaching and learning with greater urgency. Partisanship was evident in the popular press and higher education "trade" journals, where authors enthused about the benefits or detriments of online learning; at the same time, intimating that the other is second-rate or second-class.

In a proponent opinion piece in the New York Times, Taparia (2020) made a case for the financial benefits of online learning; it is cheaper and cuts college costs considerably. Also, clearly in the pro camp was a Washington Post article, whose title was all that was needed to know what side of the divide it fell; "Cuomo questions why school buildings still exist-and says New York will work with Bill Gates to 'reimagine education"' (Strauss, 2020). From Forbes, Frankfurt (2020) offered a strongly pro message wherein he concluded: "If this global pandemic has taught us anything, it's that the importance of online flexibility is absolutely critical for the sustainment of education and overall well-being." (Frankfurt, 2020, para. 10). He's not wrong, objectively speaking, in terms of the sustainment of education, at least so long as the pandemic rages across the globe. As for wellbeing, we're not convinced.

Meanwhile, on the other side of the divide, in an opinion piece from Inside Higher Ed entitled "Online Learning is not the Future of Higher Education," Herman (2020) reported on the findings of his own well-timed study: with the move to online learning taking place in the middle of the term, an opportunity arose where students could "compare the digital with the analog versions of their classes." (para. 7).

Herman asked his own students, who he described as being "digital natives" (suggesting they'd have no bias against digital technologies), to write about their experiences of online education. After roughly factoring in the major demographic variables (e.g., age, gender, ethnicity, etc.) Herman concluded, "...(T) hey hated it... All told, moving online caused 'a profound sense of loss."” (Herman, 2020, para. 9).

In deconstructing the students' comments, to better understand their dislike-and taking the pandemic-related variables into consideration-he deduced that the issue was the asynchronous nature of pre-recorded lectures and podcasts; no longer having a specified class time meant that students were essentially taking their classes alone. Missing out on human interaction turned out to be the essential factor fueling their extreme dislike of online learning. "The farther a class got from face-to-face, the less students liked it, and the less they got out of it. Conversely, the closer a class got to approximating the traditional classroom, the better." (Herman, 2020, para. 19).

More than a year on from the start of the COVID-19 pandemic-and the commensurate move to 'emergency remote online teaching/learning'-another opinion piece from The Times Higher Education reports that students are missing oncampus learning, adding a new angle of support for the con position. "The experience of online learning from their parental home has made many students keener than ever to study in face-toface settings alongside new friends, far away from where they grew up." (Hillman, 2021, para. 13).

Turning to the empirical research, while somewhat mixed in their overall findings, studies generally report that students are more often dissatisfied with their online learning experiences (Abbasi et al, 2020; Bouhnik and Marcus, 2006), and that face-toface learning is often preferable to distance learning (e.g., Picciano, 2002; Bali and Liu, 2018; Castle and McGuire, 2010) - both prior to and during the COVID-19 pandemic.

Nevertheless, online learning has been found to be effective in knowledge transfer/learning (Anggrawan and Jihadil, 2018); to promote critical thinking skills (Mansbach, 2015); and it limits the carbon intensity of course delivery (Castle and McGuire, 2010). Aspects of online instruction have even been found to meet weaker students' extended teaching needs (Brecht and Ogilby, 2008). The temporal freedom to progress through a course of study at one's own pace is another frequently cited benefit of online learning (e.g., Anderson, 2008). It has also been reported that while campus-based education has numerous advantages, for first-generation students, the anonymity provided by its digital 
complement can sometimes have greater benefits (van Belle and Kaag, 2021). To their credit, some distance educators have also shown that they understand the importance of communication, social presence and social interactions as features that should be incorporated into online learning (Khoo and Cowie, 2010; Bali and Liu, 2018; Nguyen et al., 2021).

The positive benefits of online learning notwithstanding, we argue that moving all teaching and learning online would sacrifice the positive benefits of an in-person interactive learning community, with its reciprocal social interactions and engagement with student groups; it would be the loss of campus culture. While we do believe that some online environments are able to create a sense of classroom cohesiveness, foster valuable interactions among students, and provide some conditions for learning and personal growth, this is by no means guaranteed. Small online class environments are more conducive to facilitating these kinds of goals; it is arguably more difficult to achieve such goals when online class sizes are very large, or when they are designed to be asynchronous.

To illustrate from our own experiences, in the second author's online class during the spring of 2021, there were seventeen very good students and wonderful classroom interactions. This would not likely have been possible with a much larger group. In the first author's large undergraduate class of 300-plus students-which was not designed to be delivered online-a little more than 100 attended the first "live online" lecture, remotely delivered (and recorded) during a lockdown period from her laptop at home. That number dropped successively lower with each passing week. By the end of that semester, only 30-40 "regulars" were still attending the live online lectures. Whatever the reasons (e.g., technology, motivation, time-tabling, connectivity, home environment, teaching quality, other COVID-19 concerns, etc.), these are not the descriptions of vibrant, thriving educational experiences.

Students who attend in-person classes, unlike those who learn online, can leave their classrooms and encounter a rich real-time, in-real-life (IRL) campus environment, where learning continues-with peers as well as with mentors (e.g., professors, counselors, and advisors). Students can feel part of a larger

\section{REFERENCES}

Abbasi, S., Ayoob, T., Malik, A., and Memon, S. I. (2020). Perceptions of Students Regarding E-Learning during Covid-19 at a Private Medical College. Pak J. Med. Sci. 36 (COVID19-S4), S57. doi:10.12669/pjms.36.COVID19-S4.2766

Alemán, A. M. M. (2010). College Women's Female Friendships: A Longitudinal View. J. Higher Edu. 81 (5), 553-582. doi:10.1353/jhe.2010.0004

Anderson, T. (2008). "Towards a Theory of Online Learning," in Theory and Practice of Online Learning. Editor T. Anderson 2nd Edn (Edmondton, Alberta: Athabasca University Press), 33-60.

Anggrawan, A., and Jihadil, Q. S. (2018). "Comparative Analysis of Online E-Learning and Face to Face Learning: an Experimental Study," in 2018 Third International Conference on Informatics and Computing (ICIC) (IEEE), 1-4.

Baehr, J. (2017). "Intellectual Virtues and Truth, Understanding, and Wisdom," in The Oxford Handbook of Virtue. Editor N. E. Snow (New York: Oxford University Press), 800-819. doi:10.1093/oxfordhb/9780199385195.013.3

Bali, S., and Liu, M. C. (2018). Students' Perceptions toward Online Learning and Face-To-Face Learning Courses. J. Phys. Conf. Ser. 1108 (1), 012094. doi:10.1088/1742-6596/1108/1/012094 community, and sometimes part of larger educational traditions that span decades, if not centuries. They can learn to become good "citizens" of their wider communities. (As an example, if students believe that their universities are implicated in injustice, they can lobby for change.) Students can also develop their ideals and act on them in the company of like-minded others. These on-campus IRL experiences are formative in students' lives, and the friendships they make while in college can last a lifetime.

In the face of the mutating COVID-19 virus, concerns for one's own-and one's students' - health and safety need to be paramount. Social distancing, and periodic lockdowns, which are sure to continue, foretell circumstances that will most certainly challenge broad scale return to campus life as we knew it. And while we would argue against online education becoming a permanent substitute to a campus-based education, we acknowledge that some forms of "emergency remote teaching/learning” may be necessary for a period of time.

As such, in the context of the COVID-19 pandemic and its repercussions, there is reason to temporarily consider a more complementary teaching and learning approach. This could involve distance learning and/or "emergency remote teaching" (Hodges et al., 2020) during lockdown phases, and a return to inperson on-campus instruction when and as it is safe to do so (e.g., Nordmann et al., 2020; Verde and Valero, 2021). However, we vehemently contend that the value of campus culture for students to develop and flourish, needs to be acknowledged and factored into any judgments about the relative merits of online and inperson learning; and planned for in any decisions about the "future of higher education".

\section{AUTHOR CONTRIBUTIONS}

All authors listed have made a substantial, direct, and intellectual contribution to the work and approved it for publication.

Bouhnik, D., and Marcus, T. (2006). Interaction in Distance-Learning Courses. J. Am. Soc. Inf. Sci. 57 (3), 299-305. doi:10.1002/asi.20277

Braskamp, L. A. (2008). Developing Global Citizens. J. Coll. Character 10 (1), 1-5. doi:10.2202/1940-1639.1058

Brecht, H., and Ogilby, S. (2008). Enabling a Comprehensive Teaching Strategy: Video Lectures. J. Inf. Tech. Educ. Innov. Pract. 7 (1), 71-86. doi:10.28945/198

Castle, S. R., and McGuire, C. J. (2010). An Analysis Of Student Self-Assessment Of Online, Blended, And Face-To-Face Learning Environments: Implications For Sustainable Education Delivery. Inter. Edu. Stud. 3 (3), 36-40.

Dhawan, S. (2020). Online Learning: A Panacea in the Time of COVID-19 Crisis. J. Educ. Tech. Syst. 49 (1), 5-22. doi:10.1177/0047239520934018

Eve, S., Paterlini, A., Willoughby, J. C., and Patenaude, J. (2014). Alumni Reflections. Ai 17, 157-164. doi:10.5334/ai.1711

Frankfurt, T. (2020). How the Pandemic Could Forever Change Higher Education. Available at: https://www.forbes.com/sites/forbestechcouncil/2020/05/08/howthe-pandemic-could-forever-change-higher-education/\#7840404e7b93 (Accessed September 13, 2021).

Gable, R. L. (2016). Pathways to Thriving: First-and Continuing Generation College Student Experiences at Two Elite Universities. Cambridge, Massachusetts, USA: Harvard University. Doctoral dissertation. Available at: https://core.ac.uk/ download/pdf/154880387.pdf (Accessed September 13, 2021). 
Gareis, E., Goldman, J., and Merkin, R. (2019). Promoting Intercultural friendship Among College Students. J. Int. Intercultural Commun. 12 (1), 1-22. doi:10.1080/17513057.2018.1502339

Govindarajan, V., and Srivastava, A. (2020). What the Shift to Virtual Learning Could Mean for the Future of Higher Ed. Harvard Business Review. Available at: https://hbr.org/2020/03/what-the-shift-to-virtual-learning-could-mean-forthe-future-of-higher-ed (Accessed September 13, 2021).

Grimwood, R. (2018). Producing Global Citizens?: How New Zealand Universities Implement the Concept of Global Citizenship. New Zealand Sociol. 33 (1), 97-120.

Herman, P. C. (2020). Online Learning Is Not the Future of Higher Education. Available at: https://www.insidehighered.com/digital-learning/views/2020/06/ 10/online-learning-not-future-higher-education-opinion.

Hillman, N. (2021). Has Covid Changed Everything in Education? Don't Bet on it. The Times Higher Education. Available at: https://www.timeshighereducation. com/blog/has-covid-changed-everything-education-dont-bet-onit (Accessed September 13, 2021).

Hodges, C. B., Moore, S., Lockee, B. B., Trust, T., and Bond, M. A. (2020). The Difference between Emergency Remote Teaching and Online Learning. Available at: https://vtechworks.lib.vt.edu/bitstream/handle/10919/104648/ facdev-article.pdf?sequence=1 (Accessed September 14, 2021).

Khoo, E., and Cowie, B. (2010). A Framework for Developing and Implementing an Online Learning Community. J. Open, Flexible Distance Learn. 15 (1), 47-59. doi:10.15663/wje.v15i3.79

Lefever, R. (2012). Exploring Student Understandings of Belonging on Campus. Jnl Appl. Res. HE 4 (2), 126-141. doi:10.1108/17581181211273075

Lockee, B. B. (2021). Online Education in the post-COVID Era. Nat. Electron. 4 (1), 5-6. doi:10.1038/s41928-020-00534-0

Mansbach, J. (2015). Using Technology to Develop Students' Critical Thinking Skills. Northwestern School of Professional Studies. Available at: http://dl.sps. northwestern.edu/blog/2015/09/using-technology-to-develop- studentscritical-thinking-skills/ (Accessed September 14, 2021).

Nguyen, T., Netto, C. L. M., Wilkins, J. F., Broker, P., Vargas, E. E., Sealfon, C. D., et al. (2021). Insights into Students' Experiences and Perceptions of Remote Learning Methods: From the COVID-19 Pandemic to Best Practice for the Future. Front. Edu. 6 (647), 986. doi:10.3389/feduc.2021.647986

Nordmann, E., Horlin, C., Hutchison, J., Murray, J. A., Robson, L., Seery, M. K., et al. (2020). Ten Simple Rules for Supporting a Temporary Online Pivot in Higher Education. Plos Comput. Biol. 16 (10), e1008242. doi:10.1371/ journal.pcbi. 1008242
Peterson, G. (2017). Global Citizenship Values as a Byproduct of Democratic Virtue Education. Boston, USA: Paper presented at the American Academy of Religion Annual Meeting.

Picciano, A. G. (2002). Beyond Student Perceptions: Issues of Interaction, Presence, and Performance in an Online Course. Olj 6 (1), 21-40. doi:10.24059/ olj.v6i1.1870

Strauss, V. (2020). Cuomo Questions Why School Buildings Still Exist - and Says New York Will Work with Bill Gates to 'Reimagine Education'. The Washington Post. Available at: https://www.washingtonpost.com/ education/2020/05/06/cuomo-questions-why-school-buildings-still-existsays-new-york-will-work-with-bill-gates-reimagine-education/ (Accessed September 13, 2021).

Taparia, H. (2020). The Future of College Is Online, and It's Cheaper. The New York Times. Available at: https://www.nytimes.com/2020/05/25/opinion/onlinecollege-coronavirus.html (Accessed September 14, 2020).

van Belle, J., and Kaag, J. (2021). Online Education Avoids the 'hidden Curriculum' of Cultural Expectations. The Times Higher Education. Available at: https://www.timeshighereducation.com/blog/onlineeducation-avoids-hidden-curriculum-cultural-expectations (Accessed September 13, 2021).

Verde, A., and Valero, J. M. (2021). Teaching and Learning Modalities in Higher Education during the Pandemic: Responses to Coronavirus Disease 2019 from Spain. Front. Psychol. 12 (648), 592. doi:10.3389/fpsyg.2021.648592

Conflict of Interest: The authors declare that the research was conducted in the absence of any commercial or financial relationships that could be construed as a potential conflict of interest.

Publisher's Note: All claims expressed in this article are solely those of the authors and do not necessarily represent those of their affiliated organizations, or those of the publisher, the editors, and the reviewers. Any product that may be evaluated in this article, or claim that may be made by its manufacturer, is not guaranteed or endorsed by the publisher.

Copyright (c) 2021 Scherman and Snow. This is an open-access article distributed under the terms of the Creative Commons Attribution License (CC BY). The use, distribution or reproduction in other forums is permitted, provided the original author(s) and the copyright owner(s) are credited and that the original publication in this journal is cited, in accordance with accepted academic practice. No use, distribution or reproduction is permitted which does not comply with these terms 